\title{
Effects of Phosphonate and Mefenoxam Treatments on Development of Perennial Cankers Caused by Two Phytophthora spp. on Almond
}

\author{
G. T. Browne, USDA-ARS, Department of Plant Pathology, University of California, Davis 95616; and \\ M. A. Viveros, UC Cooperative Extension, 1031 S. Mt. Vernon, Bakersfield, CA 93307
}

\begin{abstract}
Browne, G. T., and Viveros, M. A. 2005. Effects of phosphonate and mefenoxam treatments on development of perennial cankers caused by two Phytophthora spp. on almond. Plant Dis. 89:241-249.

Orchard experiments were conducted to evaluate chemical treatments for management of perennial cankers caused by Phytophthora cactorum and P. citricola on almond (Prunus dulcis) in the San Joaquin Valley of California. Single preventive foliar sprays with phosphonate were tested by wounding and inoculating tree trunks and branches with either pathogen at time intervals from 15 days to 5 months after spraying. One to 3 months after inoculation, resulting cankers were measured. Preventive foliar sprays with phosphonate in the fall or spring suppressed development of cankers for up to 5 months after treatment; mean canker lengths on the trees sprayed with phosphonate before inoculation were 22 to $98 \%$ smaller than those on trees that received no phosphonate. In subsequent tests, preventive chemigation with phosphonate in spring or summer also inhibited canker expansion. A curative topical treatment with either fosetyl-Al or mefenoxam on cankers caused by $P$. cactorum or P. citricola reduced canker expansion by 36 to $88 \%$. Neither preventive nor therapeutic treatments eradicated the pathogens from the diseased tissues, but disease ratings made 1 year after the treatments indicated extended disease suppression. Phosphonate and mefenoxam treatments can effectively manage almond scion cankers caused by $P$. cactorum or $P$. citricola.
\end{abstract}

Additional keywords: chemical control, crown rot

During the last 10 years, cankers caused by Phytophthora cactorum and P. citricola have killed many commercial almond (Prunus dulcis) trees in orchards of California's San Joaquin Valley (7). In severe cases, mortality has exceeded $5 \%$. The disease was referred to as "lethal Phytophthora canker" $(4,7)$ to distinguish it from "pruning wound canker" of almond, caused by Phytophthora syringae $(2,11)$. The latter disease typically is annual, nonlethal, and associated with pruning wounds $(2,11)$, whereas the former typically is perennial, lethal, and not associated with pruning wounds (7). We now refer to the lethal canker disease as "perennial Phytophthora canker" (PPC) and advocate reference to the pruning wound canker disease as "annual Phytophthora canker". These designations are useful because they emphasize a key epidemiological difference between the two diseases.

Perennial Phytophthora canker of almond, which kills trees by girdling the

Corresponding author: G. T. Browne

E-mail: gtbrowne@ucdavis.edu

Accepted for publication 15 September 2004.

DOI: 10.1094/PD-89-0241

This article is in the public domain and not copyrightable. It may be freely reprinted with customary crediting of the source. The American Phytopathological Society, 2005. scion, can initiate either belowground, on the root crown or base of the tree trunk, or aboveground, on upper portions of the tree trunk or its branches (7). P. cactorum often initiates the disease near the soil surface, whereas $P$. citricola typically causes the aboveground infections (7). One source of inoculum for the aboveground infections is infested debris that is blown from the orchard floor and onto almond trees during harvest. This debris tends to accumulate in natural depressions that form where main branches join tree trunks (7). These depressions are common sites of infection, perhaps because they retain rainwater and occasionally occur alongside fissures that form in the bark between opposing scaffold branches.

Improved integrated management approaches are needed for PPC. Risk of the soilborne infections is reduced by establishing the scion-rootstock union above the soil surface at planting time (almond scions are more susceptible than typical peach rootstocks to Phytophthora spp.), avoiding Phytophthora-susceptible rootstocks such as Hansen 536 (peach $\times$ almond hybrid), and using proper soil water management $(3,7)$. However, for the aboveground PPC infections, effective control measures have not been fully reported.

Metalaxyl and mefenoxam (the active isomer of metalaxyl) and phosphonates (e.g., inorganic and organic salts of phos- phonic acid) provide systemic activity against oomycetes in plants and have helped manage many diseases caused by species of Phytophthora (13). Mefenoxam is moved upward in xylem, but phosphonate is translocated both upward and downward due to its mobility in both xylem and phloem (13). Metalaxyl inhibits rRNA synthesis by oomycetes, thereby inhibiting growth of hyphae $(9,10)$. Phosphonates have a complex, incompletely understood mode of action, but evidence suggests that phosphonic acid disrupts growth of Phytophthora and intensifies host defenses $(13,15)$. Whether inorganic (i.e., mono- and di-potassium phosphonates) or alkyl (i.e., fosetyl-Al) formulations of phosphonate are used, the active ingredient is phosphonic acid $(15,22)$. Fosetyl-Al breaks down quickly in soil and plants to yield the active molecule (8).

Several reports indicate that phosphonates and/or metalaxyl control diseases caused by Phytophthora on Prunus spp. (1,25-27). However, efficacy of phosphonates has varied among different diseases caused by oomycetes (15), and there are no full reports on effects of phosphonates on almond diseases caused by $P$. cactorum or P. citricola.

In a commercial almond orchard, foliar application of phosphonate $(2.2 \mathrm{~kg} / \mathrm{ha})$, but not soil application of mefenoxam (1.1 $\mathrm{kg} / \mathrm{ha}$ ), suppressed subsequent development of cankers on shoots excised from the trees and inoculated in vitro with $P$. citricola (G. T. Browne, unpublished). The effect lasted 3 to 5 months, depending on the experiment. On excised almond branch segments bearing small cankers caused by $P$. citricola, painting the cankers with mefenoxam (37 g a.i./liter) or fosetyl-Al (96 g a.i./liter) suppressed further canker expansion (G. T. Browne, unpublished). These preliminary results led to the main objective of this research, which was to determine the effectiveness of preventive and curative systemic treatments against PPC under orchard conditions. A portion of this work was reported previously (5).

\section{MATERIALS AND METHODS}

Inocula. Isolates of $P$. cactorum (gb2759) and $P$. citricola (gb1205 or gb2758, depending on the experiment) used in this study were obtained from almond cankers in Kern County, CA. For all experiments, inoculum consisted of mycelium produced on V8 juice agar (V8A; 17 
$\mathrm{g}$ of Bacto Agar, $2 \mathrm{~g}$ of $\mathrm{CaCO}_{3}, 200 \mathrm{ml}$ of $\mathrm{V} 8$ juice, and $800 \mathrm{ml}$ of water). The cultures were incubated for 4 to 6 days at 20 to $22^{\circ} \mathrm{C}$ before inoculation. Throughout the study, sterile V8A was used as the inoculum control. Between experiments, the isolates were stored on V8A slant cultures under mineral oil at $14^{\circ} \mathrm{C}$.

Orchards. From fall 1999 to spring 2001, trials were conducted in an almond orchard planted in 1990, and from fall 2001 through 2003, trials were conducted in a similar orchard planted in 1988. The younger orchard was irrigated by a surface drip system and the older by conventional microsprinklers. Depending on the trial, the experimental trees were cultivar Nonpareil or Price on Nemaguard peach seedling rootstock. Both orchards were located near Shafter, CA, managed conventionally, and planted with trees spaced $6.4 \mathrm{~m}$ apart within rows and $7.3 \mathrm{~m}$ apart between rows. The trees in adjacent rows were offset so that they aligned diagonally. The tree trunks measured about $1 \mathrm{~m}$ in circumference at $0.4 \mathrm{~m}$ above the soil surface.

Preventive phosphonate sprays (experiments 1 to 4). Foliar sprays with phosphonate were tested for prevention of PPC caused by $P$. cactorum and P. citricola in experiments 1 through 4 . In each experiment, the equivalent of $2.2 \mathrm{~kg}$ phosphonic acid/ha was applied once as a foliar spray. Unless specified otherwise, the phosphonate formulation was NutriPhite P+K 0-28-26 (Biagro Western Sales, Inc., Visalia, CA) applied at 4.7 liters/ha in 1,630 liters of water. The mixture was applied with an air-blast sprayer (complete tree coverage, sprayer ground speed 1.9 $\mathrm{km} / \mathrm{h}$, nozzle supply line pressure 1.45 $\mathrm{MPa}$ ). The distance between borders of adjacent spray plots was at least $21.9 \mathrm{~m}$, with three or more intervening nontreated tree rows.

Experiment 1 commenced with a phosphonate treatment on 29 October 1999, about 2 months after harvest and 1 month before natural defoliation. Unsprayed trees served as the control. There were four replicate four-tree main plots per treatment, arranged in randomized complete blocks. Individual trees (subplots) within the main plots were assigned randomly to the four factorial combinations of two inoculum treatments (control and P. citricola) and two inoculation dates (17 November 1999 and 8 February 2000) selected to determine the persistence of phosphonate effects. On each date, the appropriate experimental trees were inoculated on fresh wounds made with a wood chisel. The chisel was used to remove a 1.4 $\mathrm{cm}^{2}$ square of bark from two places on opposite sides of the trunk (at 0.3 to $0.5 \mathrm{~m}$ above the soil surface; trunk circumferences 850 to $1,040 \mathrm{~mm}$, mean $962 \mathrm{~mm}$ ) and from one place on each of four main branches ( 0.7 to $1.7 \mathrm{~m}$ above the soil surface; branch circumference 140 to 700 $\mathrm{mm}$, mean $405 \mathrm{~mm}$ ). Each wound was inoculated with a $1.4 \mathrm{~cm}^{2}$ piece of V8A with or without mycelium of $P$. citricola, covered with its bark patch, and then wrapped with one to two layers of duct tape. About 2 months after inoculation (i.e., 18 January and 14 April 2000 for the 17 November and 8 February inoculations, respectively), patches of outer bark were shaved off to reveal the upper, lower, and lateral boundaries of necrosis around each point of inoculation. Canker length was measured in a direction parallel to the tree trunk or branch axis, and canker width was measured perpendicular to the axis.

Approximately 1 year after inoculation (16 November 2000), all trees in experiment 1 were rated for disease severity: $0=$ no cankers active, tree healthy; $1=$ less than half of the wounds with active (bleeding) cankers, tree appearance otherwise healthy; $2=$ most wounds with active cankers, tree appearance otherwise healthy; 3 $=$ most wounds with active cankers, tree declining (i.e., chlorosis, defoliation); 4 = most wounds with active cankers, tree dying; $5=$ tree dead as a result of PPC. Active cankers exhibited gummosis near their margins, whereas inactive cankers appeared dry.

Experiments 2, 3, and 4 were identical to experiment 1 , except for the variations described below. In experiment 2, the phosphonate treatment and a water control were applied on 8 February 2000, about 1 week before most leaf and flower buds opened. Each treatment was applied to three replicate 15 -tree main plots in a randomized complete block design. Within the main plots, single-tree subplots were assigned randomly to nine factorial treatment combinations from three inoculants (control, $P$. cactorum, and $P$. citricola) and three inoculation dates (i.e., approximately $0.6,2$, and 3 months after treatment; 29 February, 15 April, and 17 May 2000). The resulting necrosis was measured 1 month after inoculation. Experiment 3 had the same design as experiment 2, except that the phosphonate and water control sprays were applied on 31 March 2000, when tree shoot tips had elongated more than $10 \mathrm{~cm}$ since the previous dormancy. The trees were inoculated approximately $0.5,1.5$, and 2.5 months after treatment (15 April, 17 May, and 19 June 2000), and canker lengths were determined 1 month after inoculation. For experiment 4, the phosphonate source was NutriPhite P Foliar 430-8 (Biagro Western Sales, Inc., Visalia, CA), and phosphonate and control sprays were applied 1 November 2000. There were four replicate trees per treatment combination, each inoculated on two scaffolds. The inoculations occurred approximately $0.5,3.5$, and 5 months after foliar treatment (16 November 2000, 15 February 2001, and 27 March 2001, respectively), and corresponding canker lengths were determined approximately 1 to 3 months later (15 February, 27 March, and 2 May 2001, respectively). It was not possible to assess severity of disease 1 year after inoculation in experiments 2 through 4 , because after all canker data described above were obtained, grower treatments compromised the experimental treatments.

Preventive foliar spraying versus chemigation with phosphonate (experiments 5 to 7). In experiments 5 through 7 , orchard experiments similar to those described above and excised-shoot and barkdisk inoculations described below were used to assess relative efficacy of preventive phosphonate applied either by foliar spraying or chemigation. The experiments and corresponding phosphonate sources, amounts, and treatment dates were: experiment 5, Phostrol (Nufarm Americas, Inc., Burr Ridge, IL), 3.9 liters/ha $(2.0 \mathrm{~kg}$ phosphonic acid/ha) applied 19 October 2001 by a foliar spray or a chemigation; experiment 6, Phostrol, 4.5 liters/ha (2.3 $\mathrm{kg}$ phosphonic acid/ha) applied 24 April 2002 by a foliar spray or a chemigation; and experiment 7, NutriPhite $\mathrm{P}$ foliar (430-8), 4.4 liters/ha (2.1 kg phosphonic $\mathrm{acid} / \mathrm{ha}$ ) applied by a foliar spray or a chemigation, and NutriPhite P Soil (0-600), 4.4 liters/ha (4.1 $\mathrm{kg}$ phosphonic acid/ha) applied only by chemigation. All experiment 7 treatments were applied 15 July 2003. To prevent confounding foliar spraying or irrigation with phosphonate treatment, all phosphonate chemigation plots received a water-control foliar spray, all phosphonate sprayed plots received a water-control "chemigation", and all nonphosphonate (control) plots received both of the water controls. The phosphonate and control treatments each were applied to four replicate 15 -tree main plots in a randomized complete block design. Within the main plots, nine single-tree subplots were assigned randomly to factorial combinations of inoculants (control, P. cactorum, and $P$. citricola) and inoculation dates (three successive dates per experiment).

The foliar sprays with phosphonate in experiments 5 through 7 were applied as described for experiments 1 through 4 , and the chemigations were administered through a microsprinkler irrigation system. The microsprinklers (Fan-Jet Model 40 A; Bowsmith, Inc., Exeter, CA) were spaced $3.2 \mathrm{~m}$ apart in line with (and centered between) the trees in each row (two per tree). Each main plot had a dedicated set of microsprinklers fed by one water supply line. At an operating pressure of $124 \mathrm{kPa}$, the microsprinklers delivered 39 liters $/ \mathrm{h}$ in a 5m-diameter circular pattern. Some of the irrigation water hit the tree trunks at 0.2 to $0.3 \mathrm{~m}$ above the soil surface. The phosphonate for each main plot was diluted with ca. 80 liters of water and then injected into the upstream end of the microsprinkler supply line over a 15 - to 20-min period within a continuous 12 - to $24-\mathrm{h}$ irrigation cycle. Depending on the experiment, the 
injection period was preceded by 1 to $13 \mathrm{~h}$ of irrigation and succeeded by 5 to $20 \mathrm{~h}$ of irrigation.

Orchard trees were inoculated and canker data were collected in experiments 5 and 6 as described for experiments 1 through 4, except that only two scaffold branches per tree were inoculated. In addition, excised shoot segments were inoculated in experiments 5 to 7 , and excised bark disks were inoculated in experiment 7. The shoot and bark samples were cut from randomly selected trees in main plots after time intervals approximately corresponding to those used for tree inoculations. The shoot segments (diameter 1 to 2 $\mathrm{cm}$, length 20 to $25 \mathrm{~cm}$ ) were cut from scaffold branches 1 to $2 \mathrm{~m}$ above the soil surface. In experiments 5 and 6 , eight shoot segments were collected per main plot (three for inoculation with $P$. cactorum, three for $P$. citricola, and two for the control). In experiment 7 , three shoot segments were collected per pathogen per main plot; each shoot was inoculated with P. cactorum or $P$. citricola on one side and the control on the other. The bark disks (diameter $5 \mathrm{~cm}$ ) were removed from the tree trunks 10 to $20 \mathrm{~cm}$ above the soil surface. Three bark disks were collected per main plot (one for inoculation with $P$. cactorum, one for $P$. citricola, and one for the control). All shoot and bark samples were kept in polyethylene bags ( 5 to $20^{\circ} \mathrm{C}$ ) until inoculation ( 2 to 4 days after collection). Each shoot segment was inoculated by removing two 4-mm-diameter disks of bark from opposite sides of the shoot near its midpoint, replacing one of the exposed areas with a disk of mycelium and supporting V8A from a culture of $P$. cactorum or $P$. citricola, and replacing the other exposed area with a disk of sterile V8A. The inoculated wounds were wrapped with a layer of electrical tape, and the shoots were supported above free water in 6-liter humid chambers (one chamber for shoots from each replicate field block). The bark samples were inoculated by placing a mycelium disk into a 4-mm-diameter $\times 2$ mm-deep wound made with a cork borer at the center of the bark disk on the cambium side; controls received a sterile V8A disk. After inoculation, each bark sample was placed on a support $5 \mathrm{~cm}$ above free water in a 300-ml humid chamber (Magenta Co., Chicago, IL). Length and area of necrosis on the shoot segments and bark disks, respectively, were determined after 7 days at 20 to $24^{\circ} \mathrm{C}$. The cambium sides of the disks were shaved with a knife so that necrotic and healthy tissue margins were visible. Necrotic areas were traced, scanned into grayscale images, and measured using Assess software (American Phytopathological Society, St. Paul, MN).

Curative treatments (experiments 8 to 10). Experiments 8 through 10 evaluated curative topical applications on cankers caused by $P$. cactorum and $P$. citricola. In each experiment, trees were wounded and inoculated as described above. Six weeks to 7 months after inoculation, the upper, lower, and (except for experiment 9) lateral canker margins were exposed in 20 to 30 $\mathrm{cm}^{2}$ areas by shaving off patches of the bark surface. The vertical and lateral margins were marked with metal staples and 4 $\mathrm{cm}^{2}$ pieces of colored tape. Control wounds were handled similarly. The topical test treatments, which in some experiments involved additional bark preparation, were applied immediately after marking canker margins. Posttreatment canker growth was measured 3 to 4 months after topical treatment. Specific details of individual experiments follow.

For experiment 8 , each tree in five fourtree blocks of almond cultivar Price received four inoculations with $P$. citricola and four inoculations with the control on 26 October 1999. Two of the inoculations with $P$. citricola occurred on opposite quadrants of the tree trunk, alternating with two control inoculations. In addition, two main branches were inoculated once with $P$. citricola, and two others received the control. Initial canker evaluations occurred 1 December 1999, and curative topical treatments were applied the next day. The treatments included: (i) a nontreated control, (ii) aqueous fosetyl-Al (96 g a.i./liter prepared with Aliette WDG (Aventis Crop Science, North America, Research Triangle Park, NC), (iii) aqueous mefenoxam (37 g a.i./liter) prepared with Ridomil Gold EC (Syngenta, Greensboro, $\mathrm{NC}$ ), and (iv) a Cu-oil-disinfectant mixture (180 $\mathrm{g}$ of basic copper sulfate, $500 \mathrm{ml}$ of boiled linseed oil, $80 \mathrm{ml}$ of Hexol [Rite Aid, Harrisburg, PA]). Each treatment was assigned to single-tree main plots in randomized complete blocks. Just before applying the chemicals, penetrating bark cuts were made around one of the two control wounds and one of the two cankers caused by $P$. citricola on trunks and branches of each tree. The cuts were horizontal, 4 to 8 $\mathrm{cm}$ wide, and penetrated the wood slightly. When possible, they were directed downward to aid retention of the curative preparations. About one cut was made per 100 $\mathrm{cm}^{2}$ over the necrotic bark area and that within $20 \mathrm{~cm}$ of the canker or wound margin. The topical treatments were applied with a paint brush and thoroughly wet the necrotic bark and that within $20 \mathrm{~cm}$ of the canker or wound margin. The resulting application rates for the phosphonate, mefenoxam, and copper-oil mixtures were $1.0,1.0$, and $1.5 \mathrm{ml}$ per $\mathrm{cm}^{2}$ of necrotic area, respectively. The cankers were remeasured on 31 March 2000. In addition, on 15 November 2000, the experimental trees were rated for severity of PPC symptoms using the scale described in experiment 1 .

In experiment 9, topical treatments with fosetyl-Al, mefenoxam, and water were applied to cankers and wounds resulting from experiment 2. A Latin square design was used so that the curative treatments were equally represented on each age class of cankers and control wounds; there were six replicate trees per combination of curative treatment and previous inoculant. On 21 July 2000, upper and lower margins of necrosis were marked for each canker. The next day, downward-sloping cuts were made in the bark around cankers and control wounds as described for experiment 8 , except that the cuts were made on all control and pathogen inoculation sites. Immediately after bark preparation, fosetyl-Al, mefenoxam (both prepared as for experiment 8), and water control treatments were applied; a backpack sprayer (Solo Inc., Newport News, VA) was used to thoroughly wet the entire branch or trunk circumference to $30 \mathrm{~cm}$ beyond upper and lower canker and wound margins. The resulting application rates for fosetyl-Al, mefenoxam, and water were 7,8 , and $8 \mathrm{ml}$ per $\mathrm{cm}$ length of necrosis, respectively. The cankers and control wounds were remeasured on 15 November 2000.

In experiment 10 , five replicate trees were allocated to each combination of the two inoculants $(P$. cactorum and $P$. citricola) and three topical treatments (fosetyl$\mathrm{Al}$, mefenoxam, and water control) in a completely randomized design. Each tree was wounded and inoculated on 17 November 2000 with $P$. cactorum or $P$. citricola on two main branches and sterile V8A on a third main branch. On 16 February 2001, initial canker measurements were made, and the topical treatments were applied by spraying as described for experiment 9, except that no deep bark cuts were made. Fosetyl-Al, mefenoxam, and water control sprays all were applied at a rate of $2 \mathrm{ml}$ per $\mathrm{cm}^{2}$ of necrotic area. The cankers were remeasured on 3 May 2001.

Isolation of Phytophthora from experimental cankers. Bark samples were collected immediately after cankers were measured in experiments $1,3,4,8$, and 10 to determine whether the preventive or curative treatments affected viability of the pathogens. Each sample consisted of about $8 \mathrm{~cm}^{2}$ of bark, removed to the depth of the cambium from a canker margin. For control wounds, bark samples were removed in the same manner, but from areas adjacent to the wound. A sample was collected from every wound-inoculated area in experiments $1,3,4$, and 10 , and from trunk cankers in experiment 8 . Using procedures described previously (7), the bark samples were cut into $2 \times 4 \mathrm{~mm}$ pieces, and 10 to 20 pieces per bark sample (depending on experiment) were cultured on semiselective PARP medium (18) that was modified to contain corn meal agar (17 g/liter, BBL, Kansas City, MO), pimaricin (10 mg/liter), ampicillin (250 mg/liter), rifampicin (10 $\mathrm{mg} /$ liter), and pentachloronitrobenzene ( 25 $\mathrm{mg} / \mathrm{liter}$ ). The sampling scheme for experiments 1,3 , and 4 resulted in culturing 
60,120 , and 40 of the bark pieces per replicate-tree subplot, respectively. The sampling scheme for experiments 8 and 10 resulted in culturing 20 and 40 bark pieces, respectively, per replicate tree for control inoculations and 40 pieces per tree for $P$. cactorum and $P$. citricola inoculations. All isolation plates were incubated at $18^{\circ} \mathrm{C}$ in the dark and observed for at least 1 week to determine incidence of isolation of the pathogens.

Data analyses. All data were subjected to analysis of variance (ANOVA) using PROC MIXED of SAS software (SAS, Release 8.00, Cary, NC). Canker data from experiments 1 to 4 were analyzed using the split-split plot structure; the main plots were the replicate sets of trees that received preventive spray treatments, the subplots were the individual trees that were assigned to combinations of inoculants and inoculation dates, and the subsubplots were the sets of trunk or scaffold inoculation points on a tree. Experiments 5 to 8 were analyzed according to their splitplot structure, and experiments 9 and 10 were fitted to Latin square and completely randomized designs, respectively. For all experiments, subsample data values were averaged over the experimental unit before

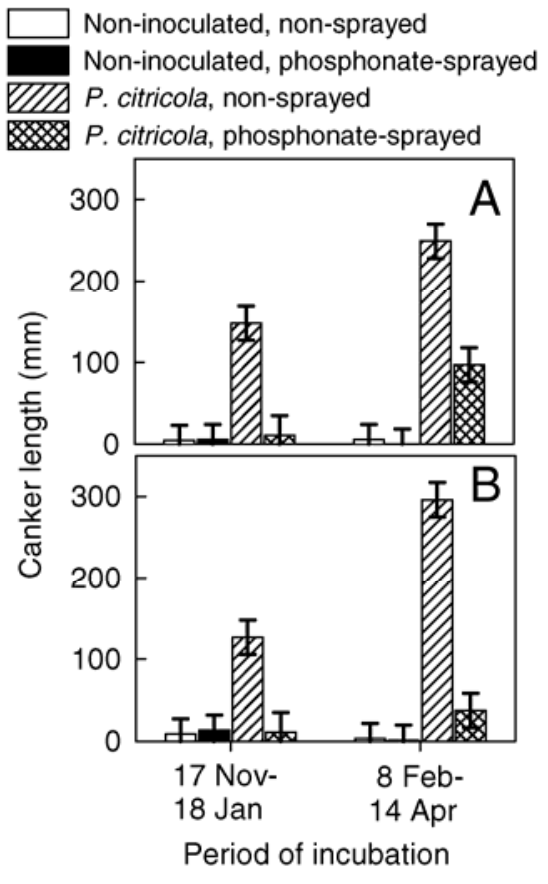

Fig. 1. Effects of a preventive foliar spray with phosphonate on development of cankers on $\mathbf{A}$, scaffold branches and $\mathbf{B}$, trunks of commercial almond trees inoculated with Phytophthora citricola in experiment 1 . NutriPhite P+K 0-2826 was applied at 4.7 liters $/ \mathrm{ha}(2.2 \mathrm{~kg}$ phosphonic acid/ha) on 29 Oct 1999. A separate set of trees was inoculated at the beginning of each period of incubation (17 Nov 1999 and 8 Feb 2000), and canker lengths were determined at the end of each period (18 Jan and 14 Apr 2000, respectively). There were four replicate trees per treatment, each inoculated twice on the trunk and once on each of four separate branches. Vertical bars are $95 \%$ confidence intervals.
ANOVA. Where appropriate, "block" and interactions with block were specified as random effects. Also, variances were pooled separately for data from noninoculated and Phytophthora-inoculated treatments by specification of a "GROUP" option within PROC MIXED, and treatment means were separated according to 95\% confidence intervals. The CORR procedure was used to evaluate statistical correlation between canker length and width on individual cankers. For all percentages of isolation of Phytophthora spp. from bark samples, the arcsine transformation was applied before analysis of variance (19); the detransformed means and 95\% confidence intervals were calculated for presentation here.

\section{RESULTS}

Dimensions of cankers. Canker length was positively correlated with canker width (determined for experiments 1 to 4,8 , and $10 ; r=0.74$ to $0.91, P<0.0001)$. The width measurements averaged 26 to $49 \%$ of the length measurements. For simplicity, only canker lengths are reported below.

Preventive phosphonate sprays (experiments 1 to 4). The foliar phosphonate spray on 29 October 1999 (experiment 1) strongly suppressed development of $P$. citricola cankers (Fig. 1). There was a highly significant four-way interaction among the following factors: spray treatment, inoculant, inoculation date, and tree part inoculated $(P=0.0015)$. Cankers caused by $P$. citricola were 93 to $61 \%$ smaller on phosphonate-sprayed trees than on nonsprayed trees, depending on inoculation date and tree part inoculated (Fig. 1). The noninoculated agar control wounds developed little necrosis, regardless of phosphonate treatment $(\leq 13 \mathrm{~mm})$. By 16 November 2000, trees that had been sprayed with phosphonate before inoculation with $P$. citricola had lower disease ratings (mean $0.4 ; 95 \%$ confidence interval $[\mathrm{CI}]=0$ to 0.8$)$ than those left nonsprayed before inoculation $(2.4, \mathrm{CI}=2.0$ to 2.9 ); the noninoculated trees all had disease ratings of zero.

The preventive phosphonate spray applied on 8 February 2000 when trees had no leaves (experiment 2) did not effectively suppress cankers caused by $P$. cactorum or $P$. citricola, although there was a significant interaction between the phosphonate and inoculation treatments $(P=$ 0.038). Canker lengths on trees treated with phosphonate before inoculation with $P$. cactorum and $P$. citricola (means 242 and $149 \mathrm{~mm}$, respectively) were nearly as great as those on trees treated with water (260 and $179 \mathrm{~mm}$, respectively), regardless of date of inoculation. Noninoculated control wounds developed little necrosis, regardless of spray treatment (12 to $17 \mathrm{~mm}$ ). Phosphonate treatment did not interact significantly with other treatment factors $(P=0.12$ to 0.53$)$.
The preventive phosphonate spray applied on 31 March 2000 after shoot growth was underway (experiment 3 ) significantly suppressed development of cankers caused by $P$. cactorum and $P$. citricola during each of the 1-month-long incubation periods (Fig. 2A). The canker lengths were affected by significant three-way interaction among spray treatment, inoculant, and inoculation date $(P<0.0001)$. Tree trunks developed longer cankers (mean $169 \mathrm{~mm}$ length) than branches (mean $156 \mathrm{~mm})(P=$ 0.01 ), but there was no significant interaction between tree part inoculated and the other treatment factors $(P=0.11$ to 0.76$)$. Following inoculation on 15 April, 17 May, and 19 June, $P$. cactorum cankers were 73,39 , and $22 \%$ smaller, respectively, and $P$. citricola cankers were 71,75 , and $66 \%$ smaller, respectively, on phosphonate-sprayed trees than on watersprayed trees. Trees inoculated with sterile agar developed little necrosis (length 19 to $54 \mathrm{~mm}$ ).

The preventive phosphonate spray applied on 1 November 2000 (experiment 4) before trees lost their leaves provided very strong initial canker suppression that slowly diminished over the next 5 months (Fig. 2B). Canker lengths on the scaffold branches were affected by interaction between spray treatment and inoculant $(P<$ $0.0001)$, spray treatment and inoculation date $(P=0.0068)$, and inoculant and inoculation date $(P<0.0001)$; but the threeway interaction was not significant $(P=$ 0.15 ) (Fig. 2B). Following inoculation on 16 November, 15 February, and 27 March, P. cactorum cankers were 91,69 , and $67 \%$ smaller, respectively, and $P$. citricola cankers were 98,79 , and $82 \%$ smaller, respectively, on phosphonate-sprayed trees than on water-sprayed trees.

Foliar spraying versus chemigation with preventive phosphonate (experiments 5 to 7). In experiment 5 , the preventive foliar phosphonate spray on 19 October significantly suppressed canker development in orchard trees during the next 6 months (incubation periods beginning 16 November, 15 February, 1 April), but the chemigation was ineffective (Table 1). For orchard tree canker lengths, interaction of inoculant $x$ chemical treatment $x$ incubation date was significant $(P=$ $0.003)$; cankers induced by $P$. cactorum and $P$. citricola were 43 to $57 \%$ and 59 to $86 \%$ smaller in phosphonate-sprayed plots, respectively, than in water-control plots (Table 1). Excised shoot canker lengths were not affected by three-way interaction involving inoculation date $(P=0.33)$ and were affected by a phosphonate $\times$ inoculum interaction $(P<0.0001)$, so the twoway treatment means combined for 24 November, 19 February, and 3 April inoculation dates are presented (Table 1). Only the foliar phosphonate treatment significantly suppressed canker expansion on shoot segments inoculated with $P$. citri- 
cola, and neither of the phosphonate treatments suppressed canker expansion caused by $P$. cactorum (Table 1 ).

In experiment 6 , effects of preventive foliar and chemigation treatments with phosphonate on 24 April varied with assay method, incubation period, and Phytophthora sp. (Table 1). Branch cankers caused by $P$. cactorum or $P$. citricola were 19 to $32 \%$ smaller on trees treated with phosphonate by foliar spraying or chemigation than on trees treated with water alone (Table 1, experiment 6 , orchard trees; phosphonate treatment $\times$ inoculum interaction significant, $P=0.001$; means combined over incubation periods due to lack of incubation period interaction with other factors). Excised shoot cankers produced by $P$. cactorum, however, only were suppressed by the preventive foliar spray and only during the first two incubation intervals (starting 17 May, 24 June). Excised shoot cankers produced by $P$. citricola were suppressed by the foliar spray during all three incubation intervals (starting 17 May, 24 June, 24 July) and by the chemigation during the last incubation interval. The three-way interaction (phosphonate treatment $\times$ inoculum $\times$ incubation interval) was significant for the excised shoot assays $(P=0.01)$.

In experiment 7 , the preventive foliar spray with phosphonate on 15 July inhibited growth of cankers produced by $P$. cactorum and $P$. citricola on excised shoots during all three incubation intervals, up to 5 months after treatment (Table 2). On the other hand, chemigation with phosphonate (either NP 4-30-8 or NP 0-60-0) only inhibited shoot cankers caused by $P$. citricola, and only during the first month after treatment (Table 2, incubation starting 15 August).

On the excised bark disks, contaminating fungi prevented meaningful treatment assessment after the 15 August incubation. For the 13 October and 16 December incubation periods, benomyl ( $7 \mathrm{~g}$ a.i./liter, sprayed on bark disks immediately after inoculation) was used to prevent the contamination. Necrotic areas induced by $P$. cactorum during the 13 October incubation were smaller on the disks from NP 0-60-0 chemigation plots than on those from the other treatments (Table 3). Necrotic areas produced by $P$. citricola during the incubation periods starting on 13 October were significantly smaller on disks from all phosphonate-treated trees (i.e., those given NP 4-30-8 foliar spray, NP 4-30-8 chemigation, or NP 0-60-0 chemigation) than on disks from trees treated with water alone (Table 3). During the last incubation (starting 16 December), only the foliar phosphonate treatment significantly inhibited development of cankers, and only for $P$. cactorum.

Curative treatments (experiments 8 to 10). In experiment 8 , painting the cankers with fosetyl-Al or mefenoxam, but not $\mathrm{Cu}-$ oil mixture, suppressed expansion of $P$. citricola cankers (Fig. 3). By the day before the curative treatments were applied (1 December 1999), all wounds inoculated with $P$. citricola had developed a canker (mean length $\times$ width $161 \times 56 \mathrm{~mm}$ for scaffolds, $148 \times 48 \mathrm{~mm}$ for trunks), but the controls had negligible amounts of necrosis $(\leq 8 \times 2 \mathrm{~mm})$. After the curative treatments, further canker expansion was affected by interactions between inoculum $x$ topical treatment and inoculum $\times$ bark preparation $(P<0.0001$ and $P=0.0006$, respectively). Final canker length was $18 \%$ less on the main branches than on trunks $(P=0.01)$, but there was no significant interaction between tree part inoculated and other treatment factors $(P=0.14$ to 0.99). The fosetyl-Al application arrested expansion of $P$. citricola cankers during the initial evaluation period (Fig. 3). Mefenoxam application significantly suppressed expansion of $P$. citricola cankers, and the effect was more pronounced on cankers given bark cuts before treatment. On 15 November 2000, the trees with fo-
setyl-Al-painted cankers had significantly lower disease severity ratings (mean 0.4; $\mathrm{CI}=0.6$ to 2.2$)$ than those with untreated cankers $(3.9 ; \mathrm{CI}=3.1$ to 4.7$)$ or $\mathrm{Cu}$-oilmixture treated cankers $(3.7 ; \mathrm{CI}=2.9$ to 4.5). The trees with mefenoxam-painted cankers had intermediate ratings $(2.5 ; \mathrm{CI}=$ 1.7 to 3.3 ).

In experiment 9, a concentrated topical spray with either fosetyl-Al or mefenoxam, applied to bark prepared with woodpenetrating cuts, strongly suppressed subsequent expansion of cankers caused by $P$. cactorum or P. citricola (Fig. 4A). Just before the treatments were applied, mean vertical lengths of the cankers on main branches inoculated with $P$. cactorum and $P$. citricola were 422 and $312 \mathrm{~mm}$, respectively, and the corresponding trunk canker lengths were 456 and $320 \mathrm{~mm}$; necrosis associated with the control wounds averaged $<8 \mathrm{~mm}$ length. Four months after the topical treatment with water, cankers caused by $P$. cactorum and $P$. citricola expanded an average of 262 and $138 \mathrm{~mm}$, respectively (Fig. 4A). Relative to the wa-

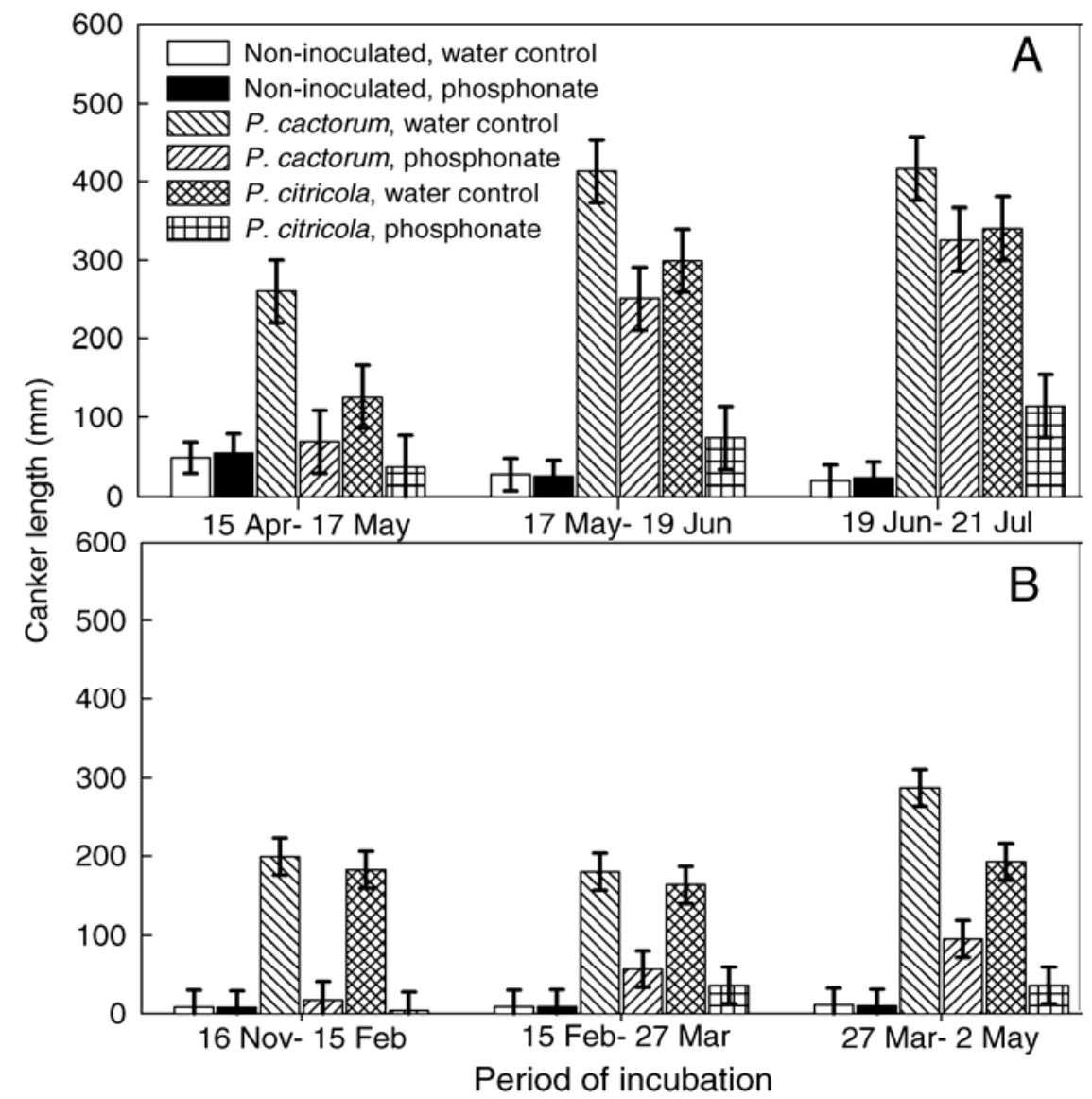

Fig. 2. Effects of a preventive foliar spray with phosphonate on development of cankers on almond trees inoculated with Phytophthora cactorum and P. citricola in $\mathbf{A}$, experiment 3 and $\mathbf{B}$, experiment 4. For experiment 3, phosphonate was applied as NutriPhite P+K 0-28-26 at 4.7 liters/ha to completely cover each tree on 31 March 2000. Control trees were sprayed with water. A separate set of trees was inoculated at the beginning of each period of incubation, and lengths of cankers were measured at the end of each period. There were three replicate trees per treatment, each inoculated at two points on the trunk and at one point on four scaffold branches. Experiment 4 was conducted in a similar manner, except that phosphonate was applied as NutriPhite P Foliar 4-30-8 at 4.7 liters/ha on 1 Nov 2000, and there were four replicate trees per treatment, each inoculated on two scaffold branches. Vertical bars are $95 \%$ confidence intervals. 
ter control, cankers caused by $P$. cactorum and P. citricola and treated with fosetyl-Al expanded 77 and $71 \%$ less, respectively, and those treated with mefenoxam expanded 79 and $54 \%$ less, respectively. The inoculum $\times$ topical treatment interaction was highly significant $(P=0.0008)$. Preventive spray treatments that were part of experiment 2 (the source of cankers treated in experiment 9) did not affect canker development in experiment $9(P=0.41$ to $0.97)$.
Topical spray application of fosetyl-Al or mefenoxam without preparatory cuts in the bark (experiment 10) strongly suppressed subsequent expansion cankers caused by $P$. cactorum and $P$. citricola, but fosetyl-Al was more effective than me-

Table 1. Effects of preventive foliar and chemigation treatments with phosphonate on development of cankers caused by two species of Phytophthora in experiments 5 and 6

\begin{tabular}{|c|c|c|c|c|c|c|c|}
\hline \multirow[b]{2}{*}{ Experiment $^{\mathbf{a}}$} & \multirow{2}{*}{$\begin{array}{c}\text { Date of } \\
\text { chemical } \\
\text { treatment }\end{array}$} & \multirow{2}{*}{$\begin{array}{l}\text { Inoculation } \\
\text { method }^{b}\end{array}$} & \multirow{2}{*}{$\begin{array}{l}\text { Incubation } \\
\operatorname{period}(\mathbf{s})\end{array}$} & \multirow{2}{*}{$\begin{array}{c}\text { Phosphonate } \\
\text { treatment }\end{array}$} & \multicolumn{3}{|c|}{ Inoculant and mean canker length $(\mathbf{m m})^{c}$} \\
\hline & & & & & Sterile control & P. cactorum & P. citricola \\
\hline \multirow[t]{12}{*}{5} & 19 Oct 2001 & Orchard tree & 16 Nov 2001-15 Feb 2002 & Water control & 19 & 185 & 173 \\
\hline & & & & Foliar spray & 16 & $79 *$ & $24 *$ \\
\hline & & & & Chemigation & 16 & 184 & 148 \\
\hline & & & 15 Feb 1-Apr 2002 & Water control & 16 & 150 & 179 \\
\hline & & & & Foliar spray & 16 & $66^{*}$ & $73 *$ \\
\hline & & & & Chemigation & 16 & 155 & 168 \\
\hline & & & 1 Apr-16 May 2002 & Water control & 23 & 369 & 336 \\
\hline & & & & Foliar spray & 27 & $210^{*}$ & $103^{*}$ \\
\hline & & & & Chemigation & 17 & 325 & 308 \\
\hline & & Excised shoot & Three combined $^{\mathrm{d}}$ & Water control & 0 & 94 & 113 \\
\hline & & & & Foliar spray & 0 & 78 & $65^{*}$ \\
\hline & & & & Chemigation & 0 & 99 & 112 \\
\hline \multirow[t]{12}{*}{6} & 24 Apr 2002 & Orchard tree & Three combined ${ }^{\mathrm{e}}$ & Water control & 19 & 452 & 368 \\
\hline & & & & Foliar spray & 17 & $358 *$ & $251^{*}$ \\
\hline & & & & Chemigation & 20 & $365^{*}$ & $262 *$ \\
\hline & & Excised shoot & 17 Мay-24 May 2002 & Water control & 1 & 120 & 102 \\
\hline & & & & Foliar spray & 2 & $55^{*}$ & $28 *$ \\
\hline & & & & Chemigation & 3 & 126 & 82 \\
\hline & & & 24 Jun-1 Jul 2002 & Water control & 0 & 121 & 124 \\
\hline & & & & Foliar spray & 0 & $84 *$ & $47 *$ \\
\hline & & & & Chemigation & 0 & 115 & 97 \\
\hline & & & 24 Jul-31 Jul 2002 & Water control & 0 & 109 & 121 \\
\hline & & & & Foliar spray & 0 & 85 & $24 *$ \\
\hline & & & & Chemigation & 0 & 93 & $47 *$ \\
\hline
\end{tabular}

a In experiments 5 and 6, Phostrol was applied at 3.9 and 4.5 liters/ha (2.0 and $2.3 \mathrm{~kg}$ of phosphonic acid/ha), respectively; within an experiment, spray and chemigation treatments received the same amount of phosphonate, and all treatments received the same amounts of water by foliar spray and irrigation.

${ }^{b}$ In the orchard tree method, wounds on two intact branches on each of four replicate trees were inoculated per factorial treatment combination of incubation period, phosphonate treatment, and inoculum treatment. In the excised shoot method, three shoot segments from each of four replicate plots were wound inoculated per treatment combination of incubation period, phosphonate treatment, and inoculation treatment involving $P$. cactorum or $P$. citricola; two shoot segments from each of four replicate plots were inoculated per treatment combination involving the sterile control.

$\mathrm{c}$ Within an incubation period and inoculant, asterisks indicate means from foliar or chemigation treatments with phosphonate that differ significantly from the corresponding mean for the water control, based on $95 \%$ confidence intervals.

${ }^{\mathrm{d}}$ Data from three incubation periods (24 Nov to 3 Dec 2001, 19 Feb to 28 Feb 2002, and 3 Apr to 10 Apr 2002) were combined due to lack of interaction between incubation period and the other treatment factors $(P=0.33)$.

e Data from three incubation periods in 2002 (15 May to 18 Jun, 18 Jun to 23 Jul, 22 Jul to 28 Aug) were combined due to lack of interaction between incubation period and the other treatment factors $(P=0.17)$.

Table 2. Effects of preventive phosphonate treatments applied by foliar spraying or chemigation on development of cankers caused by two species of $P$ hytophthora on excised shoots in experiment 7, 2003

\begin{tabular}{|c|c|c|c|c|c|}
\hline \multirow{2}{*}{$\begin{array}{l}\text { Incubation } \\
\text { period }\end{array}$} & \multirow[b]{2}{*}{ Phosphonate treatment ${ }^{a}$} & \multirow{2}{*}{$\begin{array}{l}\text { Phosphonic } \\
\text { acid (kg/ha) }\end{array}$} & \multicolumn{3}{|c|}{ Inoculant and mean canker length $(\mathrm{mm})^{b}$} \\
\hline & & & Noninoculated control & P. cactorum & P. citricola \\
\hline \multirow[t]{4}{*}{15 Aug-22 Aug } & Water control & 0 & 1 & 115 & 123 \\
\hline & Foliar spray, NP 4-30-8 & 2.1 & 1 & $41 *$ & $30 *$ \\
\hline & Chemigation, NP 4-30-8 & 2.1 & 0 & 104 & $54 *$ \\
\hline & Chemigation, NP 0-60-0 & 4.1 & 1 & 86 & $35^{*}$ \\
\hline \multirow[t]{4}{*}{13 Oct- 20 Oct } & Water control & 0 & 1 & 95 & 54 \\
\hline & Foliar spray, NP 4-30-8 & 2.1 & 0 & $34 *$ & $16^{*}$ \\
\hline & Chemigation, NP 4-30-8 & 2.1 & 2 & 89 & 45 \\
\hline & Chemigation, NP 0-60-0 & 4.1 & 1 & 72 & 29 \\
\hline \multirow[t]{4}{*}{16 Dec-23 Dec } & Water control & 0 & 0 & 60 & 56 \\
\hline & Foliar spray, NP 4-30-8 & 2.1 & 0 & $24 *$ & $13^{*}$ \\
\hline & Chemigation, NP 4-30-8 & 2.1 & 0 & 46 & 38 \\
\hline & Chemigation, NP 0-60-0 & 4.1 & 0 & 38 & 34 \\
\hline
\end{tabular}

a Phosphonate sources, all applied 15 July 2003, were NutriPhite P foliar 4-30-8 applied by foliar spraying or chemigation at 4.4 liters/ha, or NutriPhite P soil Hi-Grade 0-60-0 applied by chemigation at 4.4 liters/ha. The control received equivalent amounts of water applied by spraying and irrigation.

${ }^{\mathrm{b}}$ For each combination of incubation period, phosphonate treatment, and species of Phytophthora, three excised shoot segments from each of four replicate field plots were wounded and inoculated on one side with mycelium of the pathogen on V8 juice agar disks. On the side opposite from the wound inoculated with a Phytophthora sp., each shoot segment was wounded and inoculated with sterile V8 juice agar as a control. Within incubation periods and inoculation treatments, asterisks indicate phosphonate treatment means that differ significantly from the corresponding water-control means, based on $95 \%$ confidence intervals. 
fenoxam on cankers caused by the latter (Fig. 4B). By the day of application of the topical treatments (16 February 2001), all wounds inoculated with $P$. cactorum and $P$. citricola had cankers that averaged $189 \times$ $139 \mathrm{~mm}$ (length $\times$ width) and $150 \times 93$ $\mathrm{mm}$, respectively, and control necrosis was $19 \times 18 \mathrm{~mm}$. Compared with the water control treatment, the topical spray with fosetyl-Al reduced canker expansion caused by $P$. cactorum and $P$. citricola by 86 and $88 \%$, respectively, while mefenoxam reduced canker expansion by 80 and $52 \%$, respectively. Noninoculated control wounds developed little additional necrosis, regardless of topical treatment. Interaction between the species of Phytophthora and topical treatment was statistically significant $(P=0.001)$.

Effects of preventive and therapeutic treatments on isolation of Phytophthora spp. In some of the experiments that involved a preventive phosphonate spray treatment and included pathogen reisolations (experiments 1, 3, and 4), phosphonate treatment reduced the incidence of pathogen reisolation, but it never eradicated the pathogen(s) (Table 4; $P=0.08$ for effect of spray treatment in experiment 1; $P<0.0001$ to $P=0.008$ for effect of spray $\times$ Phytophthora $\mathrm{sp}$. in experiments 3 and 4). Isolations from the sterile-agarinoculated areas never yielded a Phytophthora sp.

In experiments that involved curative applications (experiments 8 and 10), there were marginal to significant treatment effects on the incidence of pathogen reisolation $(P=0.02$ to 0.09$)$. Nevertheless, the percentages of reisolation were low $(\leq 13 \%)$, regardless of therapeutic treatment (Table 4). The isolations from sterileagar-inoculated control wounds never yielded a Phytophthora sp.

\section{DISCUSSION}

This research indicates that properly timed preventive sprays or chemigations with phosphonate, as well as curative topical canker treatments with fosetyl-Al or mefenoxam, can improve management of PPC in almond orchards. To our knowledge, this is the first report of an effective management strategy for the disease. The results also indicate that topical treatment with the $\mathrm{Cu}$-oil mixture has no curative value for PPC caused by P. citricola.

We determined that one preventive foliar phosphonate spray in late October or early November can provide substantial protection from cankers caused by $P$. cactorum and $P$. citricola. In our experiments, the protective effect of the fall spray began within 2 to 3 weeks after treatment and lasted an additional 5 to 6 months, through early spring. The fall-through-spring period probably is critical for PPC management because it occurs when cool to moderate temperatures and free moisture on tree surfaces favor infection by the causal pathogens. In previous research, we found evidence that PPC infections had begun during winter and early spring, which included isolation of the pathogens during this period in association with small, expanding almond tree cankers and fresh necrotic lesions on volunteer almond seedlings that had collected and sprouted in natural depressions that form at the junction between the branches and trunk of almond trees (7).

After the fall treatment, the next opportunity for an effective whole-tree spray with phosphonate is in spring, after almond shoots have produced leaves. In our experiments, application of phosphonate at the end of tree dormancy was ineffective (experiment 2), probably because dormant trees lacked expanded leaves to facilitate phosphonate absorption. The preventive foliar spray with phosphonate in spring (experiment 3) strongly suppressed canker development for about 1.5 months, and after that, systemic suppression diminished

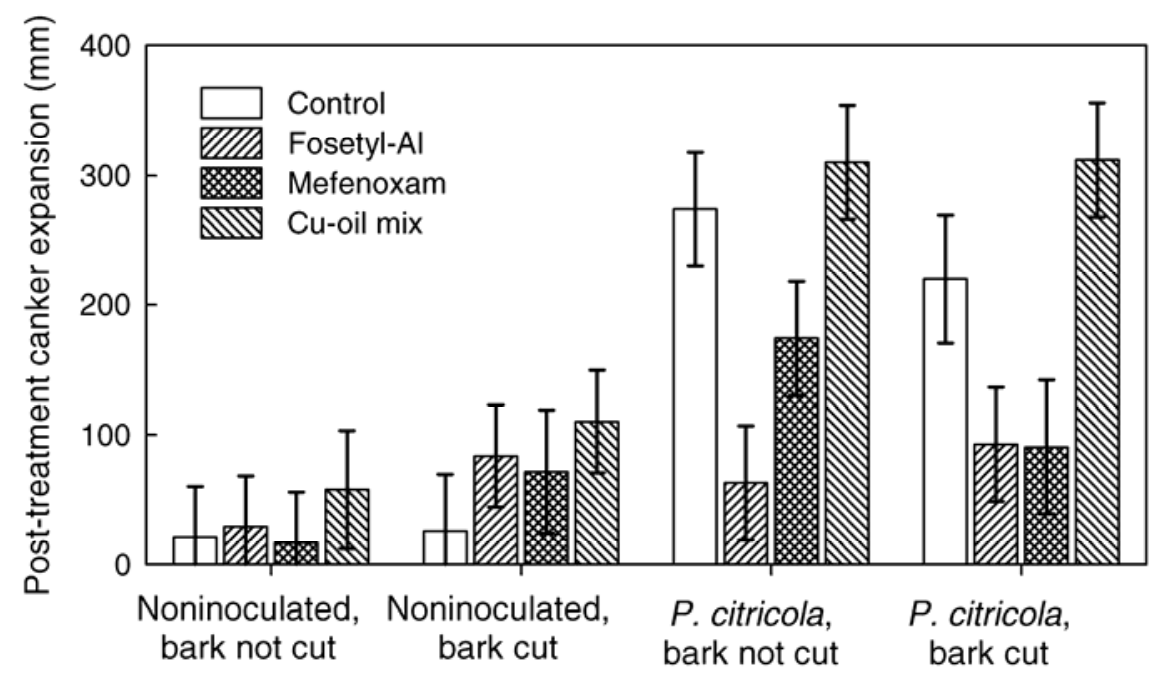

Fig. 3. Effects of curative topical treatments on development of almond scion cankers caused by Phytophthora citricola in experiment 8. Each tree was wounded and inoculated with $P$. citricola or sterile agar (noninoculated control) on 26 Oct 1999. Inoculations with the pathogen and the control each occurred on two main tree branches and on two opposite quadrants of the trunk. Cankers were allowed to develop until 1 Dec 1999, and then they were measured, marked at their margins, and painted with preparations of fosetyl-Al, mefenoxam, or a copper-and-oil mixture. Each topical treatment was applied to five replicate trees. Canker expansion was determined on 31 Mar 2000. Vertical bars are 95\% confidence intervals.

Table 3. Effects of preventive phosphonate treatments applied by foliar spraying or chemigation on development of necrosis in bark disks excised from tree trunks in experiment 7, 2003

\begin{tabular}{|c|c|c|c|c|c|}
\hline \multirow[b]{2}{*}{ Incubation period } & \multirow[b]{2}{*}{ Phosphonate treatment ${ }^{\mathrm{a}}$} & \multirow{2}{*}{$\begin{array}{l}\text { Phosphonic } \\
\text { acid (kg/ha) }\end{array}$} & \multicolumn{3}{|c|}{ Inoculant and mean area of necrosis $\left(\mathbf{m m}^{2}\right)^{b}$} \\
\hline & & & Noninoculated & P. cactorum & P. citricola \\
\hline 13 Oct- 20 Oct & $\begin{array}{l}\text { Water control } \\
\text { Foliar spray, NP 4-30-8 } \\
\text { Chemigation, NP 4-30-8 } \\
\text { Chemigation, NP 0-60-0 }\end{array}$ & $\begin{array}{c}0 \\
2.1 \\
2.1 \\
4.1\end{array}$ & $\begin{array}{l}25 \\
27 \\
25 \\
21\end{array}$ & $\begin{array}{c}662 \\
707 \\
551 \\
350^{*}\end{array}$ & $\begin{array}{c}601 \\
288^{*} \\
182^{*} \\
130^{*}\end{array}$ \\
\hline 16 Dec-23 Dec & $\begin{array}{l}\text { Water control } \\
\text { Foliar spray, NP 4-30-8 } \\
\text { Chemigation, NP 4-30-8 } \\
\text { Chemigation, NP 0-60-0 }\end{array}$ & $\begin{array}{c}0 \\
2.1 \\
2.1 \\
4.1\end{array}$ & $\begin{array}{l}36 \\
36 \\
38 \\
36\end{array}$ & $\begin{array}{c}571 \\
310^{*} \\
511 \\
380\end{array}$ & $\begin{array}{l}483 \\
343 \\
298 \\
319\end{array}$ \\
\hline
\end{tabular}

a Phosphonate sources, all applied 15 July 2003, were NutriPhite $\mathrm{P}$ foliar 4-30-8 applied by foliar spraying or chemigation at 4.4 liters/ha, or NutriPhite $\mathrm{P}$ soil Hi-Grade 0-60-0 applied by chemigation at 4.4 liters/ha. The control received equivalent amounts of water applied by spraying and irrigation.

${ }^{\mathrm{b}}$ Four replicate 5-cm-diameter excised bark disks (one per replicate field plot) were wound inoculated per treatment combination. Within incubation periods and inoculation treatments, asterisks indicate phosphonate treatment means that differ significantly from the corresponding water-control means, based on $95 \%$ confidence intervals. 
sooner for disease caused by $P$. cactorum than that caused by $P$. citricola.

Growers should limit phosphonate chemigation treatments for PPC control to periods of relatively high crop evapotranspiration $\left(\mathrm{ET}_{\mathrm{C}}\right)$, although further research is needed to fully evaluate seasonal effects on uptake of phosphonate from soil. The fall chemigation on 19 October was ineffective, possibly because of insufficient water (and phosphonate) uptake by the tree roots. Normal crop evapotranspiration $\left(\mathrm{ET}_{\mathrm{C}}\right)$ for southern San Joaquin Valley almonds in October and November totals about $30 \mathrm{~mm}$, which is only about $10 \%$ of that occurring during April and May or July and August, the sets of months that included and followed dates of effective chemigation treatments in experiments 6 and 7.

Unless PPC-affected orchards are surveyed frequently, preventive treatments are likely to be much more effective than therapeutic treatments for management of the disease because cankers expand rapidly during most of the growing season, causing extensive tree damage in less than 1 year (6). Nevertheless, results of experiments 8,9 , and 10 demonstrated the curative value of mefenoxam and fosetyl-Al

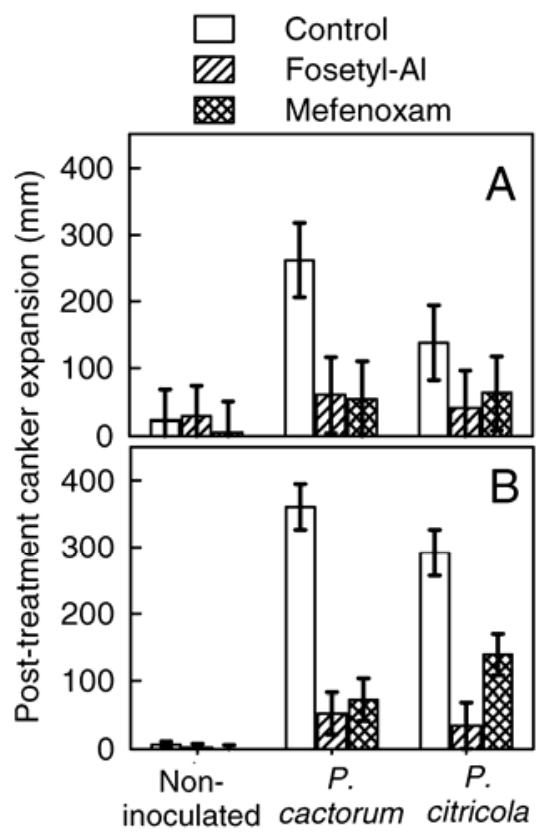

Fig. 4. Effects of curative chemical treatments on development of cankers on almond trees inoculated with Phytophthora cactorum and $P$. citricola in A, experiment 9 and $\mathbf{B}$, experiment 10. In experiment 9 , cankers caused by each pathogen and nonnecrotic control wounds were sprayed on 22 Jul 2000 and remeasured on 15 Nov 2000. There were six replicate trees per combination of curative treatment and inoculant; each tree had been inoculated on four main branches and two sides of its trunk. In experiment 10, cankers and control wounds were treated on 16 Feb 2001 and remeasured on 3 May 2001. There were five replicate trees per treatment, each inoculated on two branches. Vertical bars are $95 \%$ confidence intervals. topical treatments for control of the disease. In experiment 8 , preparatory bark cuts did not improve efficacy of topical treatment with fosetyl-Al and only slightly improved efficacy of topical treatment with mefenoxam. Therefore, deep bark cuts should be avoided because they involve greater treatment cost and increase risk of infection by Ceratocystis (24). On the other hand, shallow shaving of the bark surface helps demarcate canker areas requiring treatment. In addition to the study reported here, we completed preliminary experiments in which foliar sprays with phosphonate had therapeutic as well as preventive value for PPC management (G. T. Browne and M. A. Viveros, unpublished), but additional research is needed for complete evaluation of the therapeutic effect.

The tree disease ratings made approximately 1 year after the treatments were applied in experiments 1 and 8 indicated a long-term benefit from the preventive and curative treatments. Nevertheless, both $P$. cactorum and $P$. citricola were isolated from some of the treated cankers, which demonstrated that the treatments are not always eradicative.

We did not test repeated treatments in this research, although they may be required for optimized control of PPC. Single preventive treatments were used so that the duration of resulting effects could be determined, and our results probably represent conservative estimates of disease suppression achievable in commercial practice with repeated treatments.

Our results generally are consistent with those from related studies. For example, preventive foliar sprays with phosphonate suppressed development of cankers caused by $P$. cambivora on almond for 12 to 50 weeks, depending on treatment amount and frequency (27). Similarly, as observed for $P$. cactorum and $P$. citricola cankers on almond scions in our study, therapeutic concentrated trunk paints with fosetyl-Al or metalaxyl or a foliar spray with fosetyl$\mathrm{Al}$ strongly inhibited subsequent expansion of scion cankers caused by $P$. cactorum on peach $(23,25)$. In addition, stem treatments with metalaxyl or fosetyl-Al suppressed development of stem cankers and root and crown rot caused by $P$. cinnamomi and $P$. citricola on walnut (20). In contrast to our results with almond, however, therapeutic fosetyl-Al sprays did not inhibit expansion of cankers caused by P. cactorum on apple (16). Host, pathogen, or environmental factors could have caused this inconsistency; in addition, lesser amounts of phosphonate were applied per spray in the apple study compared with that reported here and that for peach (23). In contrast to our results with fosetyl-Al used for topical treatments on almond, bark preparation cuts improved efficacy of the fungicide for control of $P$. cactorum on apple (16) and $P$. citricola on avocado (12). Perhaps the bark shaving done to locate canker margins in our study aided fungicide penetration.

Table 4. Effects of preventive and curative chemical treatments on reisolation of Phytophthora cactorum and $P$. citricola from bark of almond trees

\begin{tabular}{|c|c|c|c|c|c|}
\hline \multirow{2}{*}{$\begin{array}{l}\text { Treatment } \\
\text { timing }\end{array}$} & \multirow[b]{2}{*}{ Experiment } & \multirow[b]{2}{*}{ Pathogen } & \multirow{2}{*}{$\begin{array}{l}\text { Chemical } \\
\text { treatment }\end{array}$} & \multicolumn{2}{|c|}{ Reisolation of pathogen ${ }^{a}(\%)$} \\
\hline & & & & Mean & $95 \% \mathrm{CI}$ \\
\hline \multirow[t]{9}{*}{ Preventive } & 1 & P. citricola & None & 11 & $6-18$ \\
\hline & & & Phosphonate & 5 & $2-10$ \\
\hline & 3 & P. cactorum & Water control & $\begin{array}{c}35 \\
9\end{array}$ & $\begin{array}{c}25-44 \\
4-16\end{array}$ \\
\hline & & P. citricola & Water control & 9 & $3-16$ \\
\hline & & & Phosphonate & 4 & $1-9$ \\
\hline & 4 & P. cactorum & Water control & 89 & $81-96$ \\
\hline & & & Phosphonate & 31 & $20-43$ \\
\hline & & P. citricola & Water control & 34 & $23-46$ \\
\hline & & & Phosphonate & 25 & $15-37$ \\
\hline \multirow[t]{7}{*}{ Curative } & 8 & P. citricola & None & 2 & $0-8$ \\
\hline & & & Fosetyl-Al & 0 & \\
\hline & & & Mefenoxam & 2 & $0-7$ \\
\hline & & & Copper-oil mixture & 9 & $3-18$ \\
\hline & $10^{\mathrm{b}}$ & P. cactorum, & Water control & 13 & $4-26$ \\
\hline & & & Phosphonate & 2 & $0-10$ \\
\hline & & & Mefenoxam & 2 & $0-9$ \\
\hline
\end{tabular}

${ }^{a}$ Based on isolations from bark samples collected from canker margins at the conclusion of experiments that involved inoculation with the pathogens. All bark samples were cultured on PARP medium. For experiments 1, 3, and 4, there were 60,120 , and 40 bark pieces cultured per replicate-tree subplot, respectively. For experiments 8 and 10, 40 bark pieces were cultured per replicate tree. Depending on experiment, 5 to 12 replicate trees were sampled per treatment combination indicated above. The isolation cultures were stored at $18^{\circ} \mathrm{C}$ in the dark and observed for at least 1 week to determine incidence of isolation of Phytophthora spp. Isolations from control wound inoculations yielded no Phytophthora sp. CI = confidence interval. All means and CIs were detransformed from arcsine values.

${ }^{\mathrm{b}}$ Means were combined for $P$. cactorum and $P$. citricola due to lack of significant interaction between Phytophthora sp. and chemical treatment. 
Interference between cankers with and without cut bark on individual tree trunks may have occurred in our study, but this effect seems unlikely for scaffold cankers, which were well separated.

Our assays of phosphonate efficacy using excised shoot segments, excised trunk bark disks, and intact orchard tree branches usually provided similar qualitative results, but there were discrepancies. For example, canker suppression sometimes occurred on shoots when it did not occur on trees, and vice versa. This suggests that multiple test methods are advisable when assessing disease suppression by phosphonate treatments in a perennial plant. The excised assays are desirable because they permit evaluation of systemic treatments without irreversible tree damage.

Continued research should help optimize phosphonate application strategies for almond and related crops. Although more costly than foliar sprays or chemigation, tree injections with phosphonate have been used with some success for other crops $(14,17,21)$ and may be useful for management of PPC on almond. In addition, development of a reliable analytical assay for phosphonate concentration in plant tissues, combined with canker response data, could help to optimize phosphonate treatment schedules.

\section{ACKNOWLEDGMENTS}

We are grateful to Bruce Mackey for helpful statistical support, and Peggy Schrader, Harold Becherer, and Steve McLaughlin for excellent technical assistance. We thank Paramount Farming, Inc. for making the field trials possible and for the valuable contributions of its staff. This work was supported in part by funding from the Almond Board of California.

\section{LITERATURE CITED}

1. Bielenin, A., and Jones, A. L. 1988. Efficacy of sprays of fosetyl-Al and drenches of metalaxyl for the control of Phytophthora root and crown rot of cherry. Plant Dis. 72:477-480.
2. Bostock, R. M., and Doster, M. A. 1985. Association of Phytophthora syringae with pruning wound cankers of almond trees. Plant Dis. 69:568-571.

3. Browne, G. T., and Becherer, H. E. 2000. Relative resistance to Phytophthora spp. among some rootstocks for almond. (Abstr.) Phytopathology 90:S10.

4. Browne, G. T., and Viveros, M. 1998. Diverse symptoms and tree losses caused by Phytophthora spp. in California almonds. Acta Hortic. 470:570-575.

5. Browne, G. T., and Viveros, M. 2000. Chemical management of lethal Phytophthora cankers on almond. (Abstr.) Phytopathology 90:S10.

6. Browne, G. T., and Viveros, M. 2001. Influence of month of inoculation on development of cankers caused by Phytophthora spp. on almond. (Abstr.) Phytopathology 91:S11.

7. Browne, G. T., and Viveros, M. A. 1999. Lethal cankers caused by Phytophthora spp. in almond scions: Specific etiology and potential inoculum sources. Plant Dis. 83:739-745.

8. Cohen, Y., and Coffey, M. D. 1986. Systemic fungicides and the control of oomycetes. Annu. Rev. Phytopathol. 24:311-338.

9. Davidse, L. C. 1987. Biochemical aspects of phenylamide fungicides--Action and resistance. Pages 275-282 in: Modern Selective Fungicides--Properties, Applications, Mechanisms of Action. H. Lyr, ed. Longman Sci. and Tech. Co. and John Wiley \& Sons, New York.

10. Davidse, L. C. 1995. Phenylamide fungicides-Properties, applications, mechanisms of action. Pages 347-354 in: Modern Selective Fungicides--Properties, Applications, Mechanisms of Action. H. Lyr, ed. 2nd ed. Gustav Fischer Verlag, Jena, Germany.

11. Doster, M. A., and Bostock, R. M. 1988. Incidence, distribution, and development of pruning wound cankers caused by Phytophthora syringae in almond orchards in California. Phytopathology 78:468-472.

12. El-Hamalawi, Z. A., Menge, J. A., and Adams, C. J. 1995. Methods of fosetyl-Al application and phosphonate levels in avocado tissue needed to control stem canker caused by Phytophthora citricola. Plant Dis. 79:770-778.

13. Erwin, D. C., and Ribeiro, O. K. 1996. Chemical control. Pages 211-237 in: Phytophthora Diseases Worldwide. American Phytopathological Society, St. Paul, MN.

14. Guest, D. I., Anderson, R. D., Foard, H. J., Phillips, D., Worboys, S., and Middleton, R.
M. 1994. Long-term control of Phytophthora diseases of cocoa using trunk-injected phosphonate. Plant Pathol. 43(3):479-492.

15. Guest, D. I., and Grant, B. 1991. The complex action of phosphonates as antifungal agents. Biol. Rev. 66:159-187.

16. Harris, D. C. 1987. Orchard trials on the control of apple collar rot. J. Hortic. Sci. 62:441447.

17. Holderness, M. 1992. Comparison of metalaxyl/cuprous oxide sprays and potassium phosphonate as sprays and trunk injections for control of Phytophthora palmivora pod rot and canker of cocoa. Crop Prot. 11:141-147.

18. Kannwischer, M. E., and Mitchell, D. J. 1978. The influence of a fungicide on the epidemiology of black shank of tobacco. Phytopathology 68:1760-1765.

19. Little, T. M., and Hills, F. J. 1978. Transformations. Pages 139-164 in: Agricultural Experimentation, Design and Analysis. John Wiley \& Sons, New York.

20. Matheron, M. E., and Mircetich, S. M. 1985. Control of Phytophthora root and crown rot and trunk canker in walnut with metalaxyl and fosetyl Al. Plant Dis. 69:1042-1043.

21. Opoku, I. Y., Akrofi, A. Y., Appiah, A. A., and Luterbacher, M. C. 1998. Trunk injection of potassium phosphonate for the control of black pod disease of cocoa. Trop. Sci. 38:179-185.

22. Ouimette, D. G., and Coffey, M. D. 1989 Comparative antifungal activity of four phosphonate compounds against isolates of nine Phytophthora species. Phytopathology 79:761767.

23. Taylor, P. A., and Washington, W. S. 1984 Curative treatments for Phytophthora cactorum in peach trees using metalaxyl and phosethyl Al. Australas. Plant Pathol. 13:31 33.

24. Teviotdale, B. L., and Harper, D. H. 1991. Infection of pruning and small bark wounds in almond by Ceratocystis fimbriata. Plant Dis. 75:1026-1030.

25. Thomidis, T., and Elena, K. 2001. Effects of metalaxyl, fosetyl-Al, dimethomorph and cymoxanil on Phytophthora cactorum of peach tree. J. Phytopathol. 149:97-101.

26. Wicks, T. J. 1988. Effect of metalaxyl on the control of Phytophthora crown rot of almonds. Aust.. Exp. Agric. 28:547-552.

27. Wicks, T. J., and Hall, B. 1990. Control of Phytophthora canker with phosphonate in artificially inoculated almond and cherry trees. Aust. J. Exp. Agric. 30:413-420. 